\title{
LAJU PERTUMBUHAN LIMA GENOTIP UBI JALAR (Ipomoea batatas L.) YANG DIBERI KOMBINASI BOKASHI JERAMI DAN PUPUK KALIUM DI LAHAN KERING
}

\author{
Growth Rate of Five Genotypes of Sweet Potato \\ (Ipomoea batatas L.) are Given byCombination \\ Fertilizer of StrawBokashi and Potassium on Dry Land
}

\author{
Hanny Hidayati Nafi'ah ${ }^{1}$ dan Agung Karuniawan ${ }^{2}$ \\ ${ }^{1}$ Fakultas Pertanian Universitas Garut, Garut, Indonesia \\ Jalan Raya Samarang No. 52 A Tarogong Kaler 44151 \\ ${ }^{2}$ Fakultas Pertanian Universitas Padjadjaran, Bandung, \\ Indonesia \\ Jalan Raya Bandung Sumedang Km.21 Jatinangor 45363 \\ E-mail : nenghanny09@yahoo.co.id
}

\begin{abstract}
Abstrak
Ubi jalar merupakan tanaman yang sangat membutuhkan kalium untuk pembentukkan ubi. Jerami merupakan limbah tanaman yang mengandung banyak unsur kalium,jika jerami digunakan sebagai pupuk organik, maka dapat mensubtitusi penggunaan pupuk KCl. Rancangan percobaan yang digunakan pada masing-masing lahan adalah rancangan acak kelompok (RAK) pola faktorial $5 \times 7$ yang diulang dua kali. Faktor genotip yang terdiri dari 5 taraf faktor, yaitu : A; 95 [265 (653)], B; 103 [199 (294)], C; 51 [120 (371)], D; 52 [142 (275)], dan E; [Check (Rancing)]. Faktor kombinasi bokashi jerami dan pupuk kalium terdiri dari 7 taraf faktor, yaitu .1 $(0 \mathrm{t} / \mathrm{ha} \mathrm{KCl}+0 \mathrm{t} / \mathrm{ha}$ Bokashi), 2 (50 t/ha KCl + $10 \mathrm{t} / \mathrm{ha}$ Bokashi), $3(100 \mathrm{t} / \mathrm{ha} \mathrm{KCl}+10 \mathrm{t} / \mathrm{ha}$ Bokashi), 4 (50 t/ha KCl +15 t/ha Bokashi), 5 (100 t/ha KCl + 15 t/ha Bokashi), 6 (50 t/ha KCl +20 t/ha Bokashi), dan 7 (100 t/ha $\mathrm{KCl}+20$ tha Bokashi). Lima genotip ubi jalar memiliki kurva laju pertumbuhan yang berbeda untuk setiap perlakuan kombinasi pupuk $\mathrm{KCl}$ dan bokashi jerami. Respons lima genotip ubi jalar berbeda untuk setiap dosis kombinasi pupuk yang diberikan. Genotip B; 103 [199 (294)] respons terhadap subtitusi KCl dengan bokashi jerami.
\end{abstract}

Kata Kunci : Laju Pertumbuhan, Kombinasi Pupuk, Subtitusi Pupuk, Bokashi Jerami, Kalium. 


\begin{abstract}
The sweet potatoes need potassium for the formation of potato. Straw is a waste plant containing high potassium elements, if straw is used as organic fertilizer, it can be substituted for the use of inorganic potassium fertilizers. The experimental design used in each field is a randomized block design (RBD) factorial design $5 \times 7$ are repeated twice. Genotypic which consists of 5 level factors, namely: A; 95 [265 (653)], B; 103 [199 (294)], C; 51 [120 (371)], D; 52 [142 (275)], and E; [Check (Rancing)]. Factors combination fertilizer of Straw Bokashi and $\mathrm{KCl}$ consists of 7 level factor, ie. 1 ( $0 \mathrm{t} / \mathrm{ha} \mathrm{KCl}+\mathrm{Ot} / \mathrm{ha}$ Bokashi), 2 (50 t/ ha $\mathrm{KCl}$ + 10 t / ha Bokashi), 3 (100 t / ha KCl + 10 t / ha Bokashi), 4 (50 t / ha KCl + $15 \mathrm{t} /$ ha Bokashi), 5 (100 $t$ / ha $\mathrm{KCl}+15 \mathrm{t} / \mathrm{ha}$ Bokashi), 6 (50 t / ha KCl + $20 \mathrm{t} / \mathrm{ha}$ Bokashi), and 7 (100 t / ha $\mathrm{KCl}+20 \mathrm{t} /$ ha Bokashi). Five genotypes of sweet potato have different growth curves for each treatment combination fertilizer of straw Bokashi and KCl. Five genotypes of sweet potato has different responses for each dose combinations of fertilizers applied. Genotype B; 103 [199 (294)] in response to substitution of $\mathrm{KCl}$ with Bokashi straw.
\end{abstract}

Keywords: Growth Rate, Combination Fertilizer, Fertilizers substitution, Straw Bokashi, Potassium.

\section{PENDAHULUAN}

$\begin{array}{ccr}\text { Ubi } & \text { jalar memiliki } \\ \text { peringkat } & \text { kelima } & \text { sebagai } \\ \text { tanaman } & \text { pangan yang }\end{array}$ paling penting setelah beras, gandum, jagung dan ubi kayu di negara-negara berkembang (Som, 2007). Ubi jalar kaya akan vitamin $\mathrm{A}, \mathrm{B}$, dan C; juga kaya akan mineral seperti $\mathrm{K}, \mathrm{Na}, \mathrm{Cl}, \mathrm{P}$ dan $\mathrm{Ca}$ (Onwueme \& Sinha, 1991). Penelitian Hussein et. al (2014), menunjukkan bahwa ubi jalar jingga memiliki nilai total karoten $382.217(\mu \mathrm{g} / \mathrm{g})$ basis kering, dan ubi jalar kuning 122.962 $(\mu \mathrm{g} / \mathrm{g})$ basis kering.
Ubi jalar merupakan tanaman yang sangat membutuhkan kalium untuk pembentukkan ubi, kalium yang biasa digunakan adalah $\mathrm{KCl}$. Hasil penelitian Paulus (2011) menunjukkan bahwa hasil ubi jalar meningkat sejalan dengan peningkatan dosis kalium. Jerami merupakan limbah tanaman yang mengandung banyak unsur kalium, mengembalikan jerami ke tanah dapat memenuhi sebagian hara $K$ yang dibutuhkan tanaman (Warta Penelitian dan Pengembangan Pertanian, 
2009). Jika jerami digunakan sebagai pupuk organik, maka dapat mensubtitusi penggunaan pupuk $\mathrm{KCl}$, selain itu banyak keuntungan yang akan di dapat, diantaranya adalah tanah dapat mengikat air lebih lama, dapat memperbaiki tekstur tanah, serta meningkatkan daya jerap dan kapasitas tukar kation (KTK) (Munawar, 2011).

Penanaman ubi jalar biasa dilakukan di lahan kering atau di lahan sawah untuk rotasi tanaman setelah padi. Kelebihan lahan kering adalah lebih gembur dan lebih mudah diolah, ubi dapat leluasa terbentuk karena tanah tidak terlalu padat, namun kekurangan lahan kering adalah tidak dapat mengikat air terlalu lama. Pemberian pupuk jerami dalam bentuk bokashi bisa memperbaiki ketidakmampuan lahan kering dalam mengikat air tersedia bagi tanaman, dan juga sekaligus dapat mensubtitusi pupuk anorganik.

Tujuan penelitian ini adalah untuk mengetahui : 1) Kurva laju pertumbuhan lima genotip ubi jalar terhadap pemberian kombinasi pupuk $\mathrm{KCl}$ dan bokashi jerami. 2) Respons lima genotip ubi jalar untuk setiap dosis kombinasi pupuk yang diberikan. 3) Genotip ubi jalar yang respons terhadap subtitusi $\mathrm{KCl}$ dengan bokashi jerami. Kalium menjadi nutrisi paling penting dalam produksi ubi jalar dengan meningkatkan

penerapannya akan menghasilkan pembentukan ubi berukuran lebih besar. Kalium juga mempengaruhi jumlah, ukuran, kualitas dan berat satuan ubi jalar, sedangkan tingkat minimum Kalium disarankan dua kali lebih banyak dibandingkan Nitrogen (Degras, 2003).Hasil penelitian Paulus (2011) menunjukkan bahwa hasil ubi jalar meningkat sejalan dengan peningkatan dosis kalium.

Hasil Ubi jalar secara signifikan menurun jika kekurangan Kalium. Di Jepang, diperkirakan bahwa hasil ubi jalar 13 t/ha, membutuhkan sekitar $70 \mathrm{~kg}$ $\mathrm{N} / \mathrm{ha}, 20 \mathrm{~kg} \mathrm{P}_{2} \mathrm{O}_{5} / \mathrm{ha}$ dan $110 \mathrm{~kg} \mathrm{~K} \mathrm{~K}_{2} \mathrm{O} / \mathrm{ha}$ dari tanah bergantung pada durasi tanaman dan agroklimat wilayah (Degras, 2003). Perbandingan semacam ini jarang terjadi untuk daerah tropis tetapi angka yang diberikan oleh IFA (1992) menggambarkan pentingnya kalium terutama di akar dan nitrogen dalam daun. Rekomendasi umum di sebagian besar negara adalah $35-65 \mathrm{~kg} \mathrm{~N}, 50-100$ 
$\mathrm{kg} \mathrm{P}_{2} \mathrm{O}_{5}$ dan $\mathrm{K}_{2} \mathrm{O}$ 80-170 kg per hektar (IFA , 1992). Di provinsi Hubei China, tingkat Kalium optimum bervariasi 150-300 kg K ${ }_{2} \mathrm{O} / \mathrm{ha}$ (Lu Jianwei et al., 2001). Sedangkan di India, kebutuhan optimum rata-rata ditempatkan di 120 $\mathrm{kg} \mathrm{K}_{2} \mathrm{O} / \mathrm{ha}$, dan maksimum adalah $160 \mathrm{~kg} \quad \mathrm{~K}_{2} \mathrm{O} / \mathrm{ha}$ dengan respon hasil 6,7 t/ ha (Trehan et al., 2007). Kombinasi bokashi jerami 20 ton/ha dengan pupuk anorganik $1 / 2$ dosis anjuran dapat meningkatkan hasil buah tomat (Pangaribuandkk, 2011). Martodenso dan Suryanto (2001), menggunakan dosis pupuk organik 15-20 t/haterhadap tanaman ubi jalar.

\section{METODOLOGI}

Percobaan

dilaksanakan di Kebun Percobaan Universitas Padjadjaran Ciparanje Jatinangor, Kabupaten Sumedang, Provinsi Jawa Barat. Lokasi percobaan berada pada ketinggian 720 $\mathrm{m}$ dpl, dengan rata-rata curah hujan 175,3 $\mathrm{mm}$ per bulan dan suhu harian $18,1^{\circ} \mathrm{C}$. Percobaan dimulai pada bulan Februari dan berakhir Agustus 2015. Rancangan

percobaan yang digunakan pada masing-masing lahan adalah Rancangan Acak
Kelompok (RAK) pola faktorial $5 \times 7$ yang diulang dua kali. Faktor genotip yang terdiri dari 5 taraf faktor, yaitu : A; 95 [265 (653)], B; 103 [199 (294)], C; 51 [120 (371)], D; 52 [142 (275)], dan E; [Check (Rancing)]. Faktor kombinasi bokashi jerami dan pupuk kaliuk terdiri dari 7 taraf faktor, yaitu .1 (0 t/ha KCl + $0 \mathrm{t} /$ ha Bokashi), 2 (50 t/ha $\mathrm{KCl}+10 \mathrm{t} / \mathrm{ha}$ Bokashi), 3 $(100 \mathrm{t} / \mathrm{ha} \mathrm{KCl}+10 \mathrm{t} / \mathrm{ha}$ Bokashi), 4 (50 t/ha $\mathrm{KCl}+$ $15 \mathrm{t} /$ ha Bokashi), 5 (100 t/ha $\mathrm{KCl}+15 \mathrm{t} / \mathrm{ha}$ Bokashi), 6 (50 t/ha KCl $+20 \mathrm{t} / \mathrm{ha}$ Bokashi), dan 7 (100 t/ha $\mathrm{KCl}+20 \mathrm{t} /$ ha Bokashi).

Bibit ubi jalar berupa stek batang dengan panjang $20 \mathrm{~cm}$. Terdapat 560 stek per genotip untuk satu lahan.Plot berbentuk bedengan dengan panjang 2 meter dan lebar 4 meter. Jarak antar plot $30 \mathrm{~cm}$ dengan kedalaman $40 \mathrm{~cm}$ yang sekaligus berfungsi sebagai parit. Dalam satu plot terdiri dari 4 gulud dengan panjang $40 \mathrm{~cm}$ dan lebar $2 \mathrm{~m}$, jarak antar gulud $60 \mathrm{~cm}$.

Aplikasi kombinasi bokashi jerami dan $\mathrm{KCl}$. Untuk dosis bokashi 10 ton/ha setara dengan 8 $\mathrm{kg} /$ plot, untuk dosis bokashi 15 ton/ha setara dengan 10 $\mathrm{kg} /$ plot, untuk dosis bokashi 20 ton/ha setara dengan 16 
$\mathrm{kg} / \mathrm{plot}$, untuk dosis anjuran $\mathrm{KCl} 100 \mathrm{~kg} / \mathrm{ha}$ setara dengan $80 \mathrm{~g} / \mathrm{plot}$, untuk dosis anjuran $\mathrm{KCl} 50 \mathrm{~kg} / \mathrm{ha}$ setara dengan $40 \mathrm{~g} /$ plot. Bokashi jerami dicampur dengan tanah pada setiap plot sesuai perlakuan, kemudian di diamkan selama 2 minggu. $\mathrm{KCl}$ diaplikasikan di samping lubang tanam pada setiap plot sesuai perlakuan. Stek batang ubi jalar yang ditanam berbentuk $L$ dengan arah serempak, ini bertujuan agar arah pertumbuhan akar serempak. Lubang tanam dibut dengan kedalaman 5 $\mathrm{cm}$. Populasi tanaman per plot diatur berdasarkan perlakuan. Kombinasi pupuk inilah yang ingin diketahui pengaruhnya dalam laju asimilasi bersih (LAB) dan laju tumbuh tanaman (LTT) ubi jalar di lahan sawah dan lahan kering.

Pengukuran LAB dan LTT dimulai pada saat tanaman berumur 30 HST.Sampel tanaman diambil setiap interval 10 hari sampai tanaman berumur 70 HST. Data yang diperoleh dihitung menggunakan rumus :

$$
\begin{aligned}
& L A B \\
& =\frac{W 2-W 1}{T 2-T 1} \\
& \times \frac{\ln L 2-\ln L 1}{L 2-L 1}
\end{aligned}
$$

Keterangan :

$\mathrm{W}=$ bobot kering total tanaman, $\mathrm{A}=$ luas tanah, $\mathrm{T}=$ waktu pengamatan, $L=$ luas daun.

$$
L T T=\frac{W 2-W 1}{A(T 2-T 1)}
$$

Keterangan :

$\mathrm{W}=$ bobot kering total tanaman, $\mathrm{A}=$ luas tanah, $\mathrm{T}=$ waktu pengamatan.

HASIL

\section{PEMBAHASAN}

\section{Laju Asimilasi Bersih}

LAB merupakan ukuran rata-rata efisiensi fotosintesis daun dalam suatu komunitas tanaman. Bertambahnya jumlah daun yang diiringi dengan bertambahnya indeks luas daun maka makin banyak daun yang terlindungi karena daun akan saling menutupi yang menyebabkan penurunan LAB sepanjang musim pertumbuhan (Gardner et al., 1991). Untuk tanaman yang memiliki daun terlalu rimbun, akan menurunkan nilai LAB. Nilai LAB akan sangat tinggi pada saat tanaman masih kecil, dan akan menurun jika sudah banya daun yang mengalami penuaan. Stoskopf

(1981) 


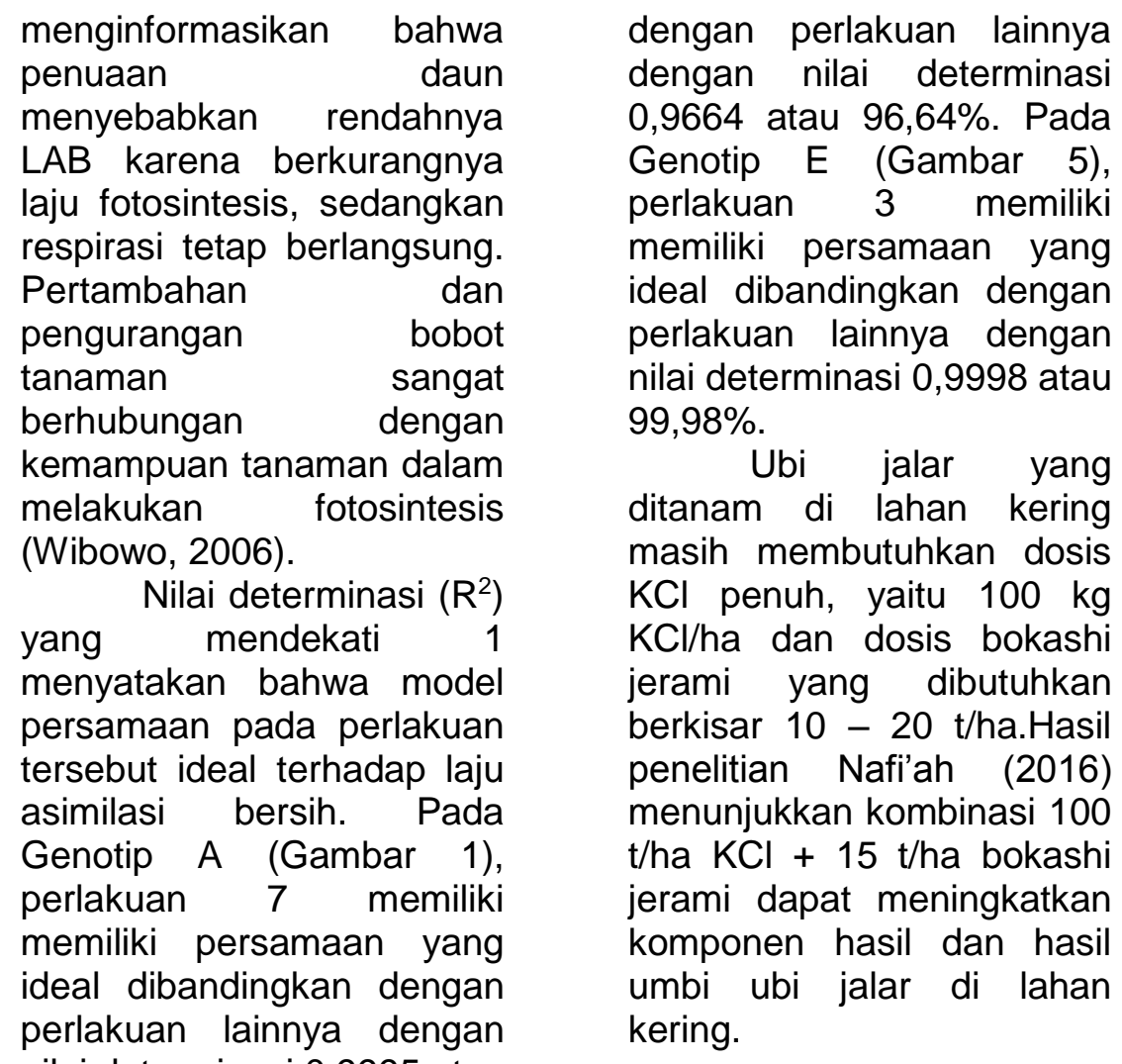

nilai determinasi 0,9995 atau 99,95\%. Pada Genotip B (Gambar 2), perlakuan 2 memiliki memiliki persamaan yang ideal dibandingkan dengan perlakuan lainnya dengan nilai determinasi 0,9036 atau $90,36 \%$. Pada Genotip C (Gambar 3), perlakuan 7 memiliki memiliki persamaan yang ideal dibandingkan dengan perlakuan lainnya dengan nilai determinasi 0,9786 atau 97,86\%. Pada Genotip D (Gambar 4), perlakuan 7 memiliki memiliki persamaan yang ideal dibandingkan 


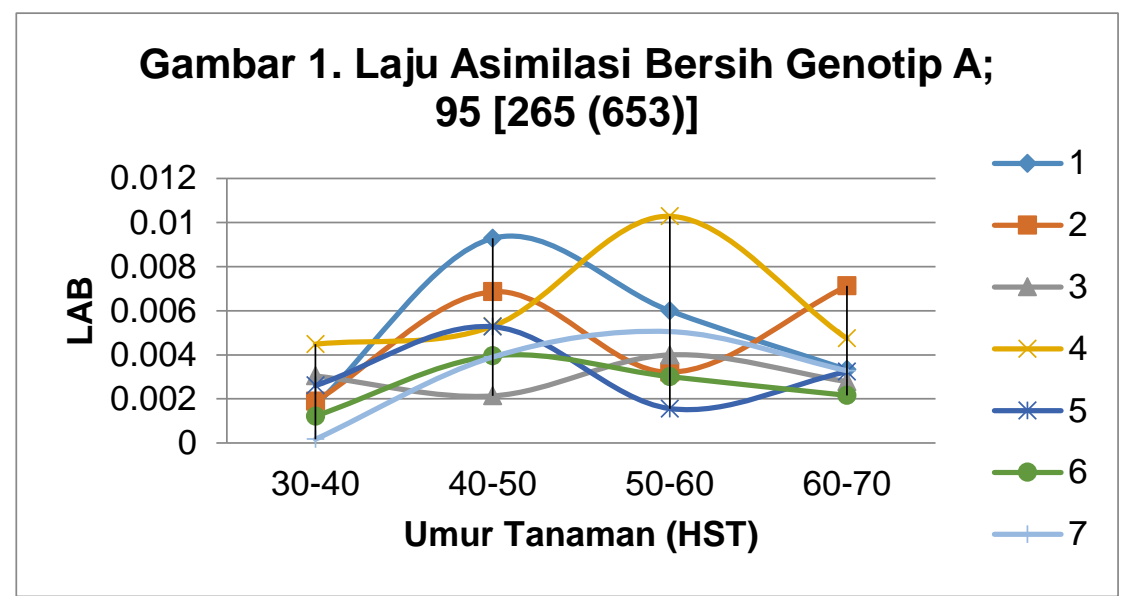

\begin{tabular}{|c|c|c|}
\hline \multicolumn{3}{|c|}{ Model Regresi } \\
\hline $1(0 \mathrm{~kg} \mathrm{KCl} / \mathrm{ha}+0$ t Bokashi/ha) & $y=-0.0026 x^{2}+0.0129 x-0.0081$ & $R^{2}=0.7999$ \\
\hline $2(50 \mathrm{~kg} \mathrm{KCl} / \mathrm{ha}+10$ t Bokashi/ha $)$ & $y=-0.0003 x^{2}+0.0025 x+0.0004$ & $R^{2}=0.3657$ \\
\hline $3(100 \mathrm{~kg} \mathrm{KCl} / \mathrm{ha}+10$ t Bokashi/ha) & $y=-8 E-05 x^{2}+0.0005 x+0.0023$ & $R^{2}=0.0467$ \\
\hline $4(50 \mathrm{~kg} \mathrm{KCl} / \mathrm{ha}+15$ t Bokashi/ha) & $y=-0.0016 x^{2}+0.0085 x-0.0032$ & $R^{2}=0.5207$ \\
\hline $5(100 \mathrm{~kg} \mathrm{KCl} / \mathrm{ha}+15 \mathrm{t}$ Bokashi/ha) & $y=-0.0002 x^{2}+0.0011 x+0.0024$ & $R^{2}=0.0567$ \\
\hline $6(50 \mathrm{~kg} \mathrm{KCl} / \mathrm{ha}+20$ t Bokashi/ha) & $y=-0.0009 x^{2}+0.0047 x-0.0024$ & $R^{2}=0.8278$ \\
\hline $7(100 \mathrm{~kg} \mathrm{KCl} / \mathrm{ha}+20$ t Bokashi/ha) & $y=-0.0014 x^{2}+0.0079 x-0.0064$ & $R^{2}=0.9995$ \\
\hline
\end{tabular}

Gambar 2. Laju Asimilasi Bersih Genotip B; 103 [199 (294)]

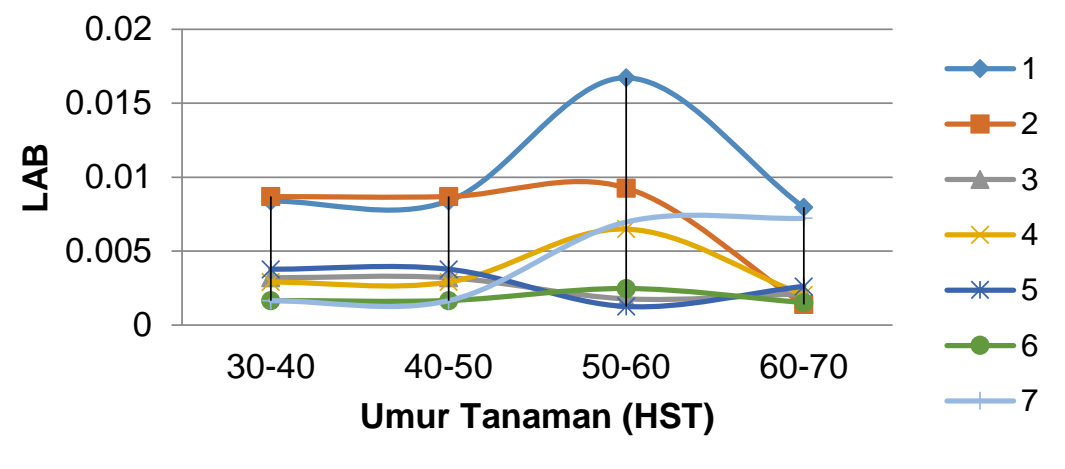




\begin{tabular}{|c|c|c|}
\hline \multicolumn{3}{|c|}{ Model Regresi } \\
\hline 1 (0 kg KCl/ha + 0 t Bokashi/ha) & $y=-0.0022 x^{2}+0.0117 x-0.0023$ & 4014 \\
\hline $2(50 \mathrm{~kg} \mathrm{KCl} / \mathrm{ha}+10 \mathrm{t}$ Bokashi/ha) & $y=-0.002 x^{2}+0.0077 x+0.0025$ & $\mathrm{R}^{2}=0.9036$ \\
\hline $3(100 \mathrm{~kg} \mathrm{KCl} / \mathrm{ha}+10$ t Bokashi/ha $)$ & $y=8 E-05 x^{2}-0.0009 x+0.0042$ & $R^{2}=0.6885$ \\
\hline $4(50 \mathrm{~kg} \mathrm{KCl} / \mathrm{ha}+15 \mathrm{t}$ Bokashi/ha $)$ & $y=-0.0011 x^{2}+0.0057 x-0.0022$ & $\mathrm{R}^{2}=0.426$ \\
\hline $5(100 \mathrm{~kg} \mathrm{KCl} / \mathrm{ha}+15$ t Bokashi/ha $)$ & $y=0.0003 x^{2}-0.0023 x+0.0061$ & $R^{2}=0.5243$ \\
\hline $6(50 \mathrm{~kg} \mathrm{KCl} / \mathrm{ha}+20 \mathrm{t}$ Bokashi/ha $)$ & $y=-0.0002 x^{2}+0.0012 x+0.0005$ & $\mathrm{R}^{2}=0.4145$ \\
\hline $7(100 \mathrm{~kg} \mathrm{KCl} / \mathrm{ha}+20$ t Bokashi/ha) & $y=6 E-05 x^{2}+0.0019 x-0.0008$ & $\mathrm{R}^{2}=0.8182$ \\
\hline
\end{tabular}

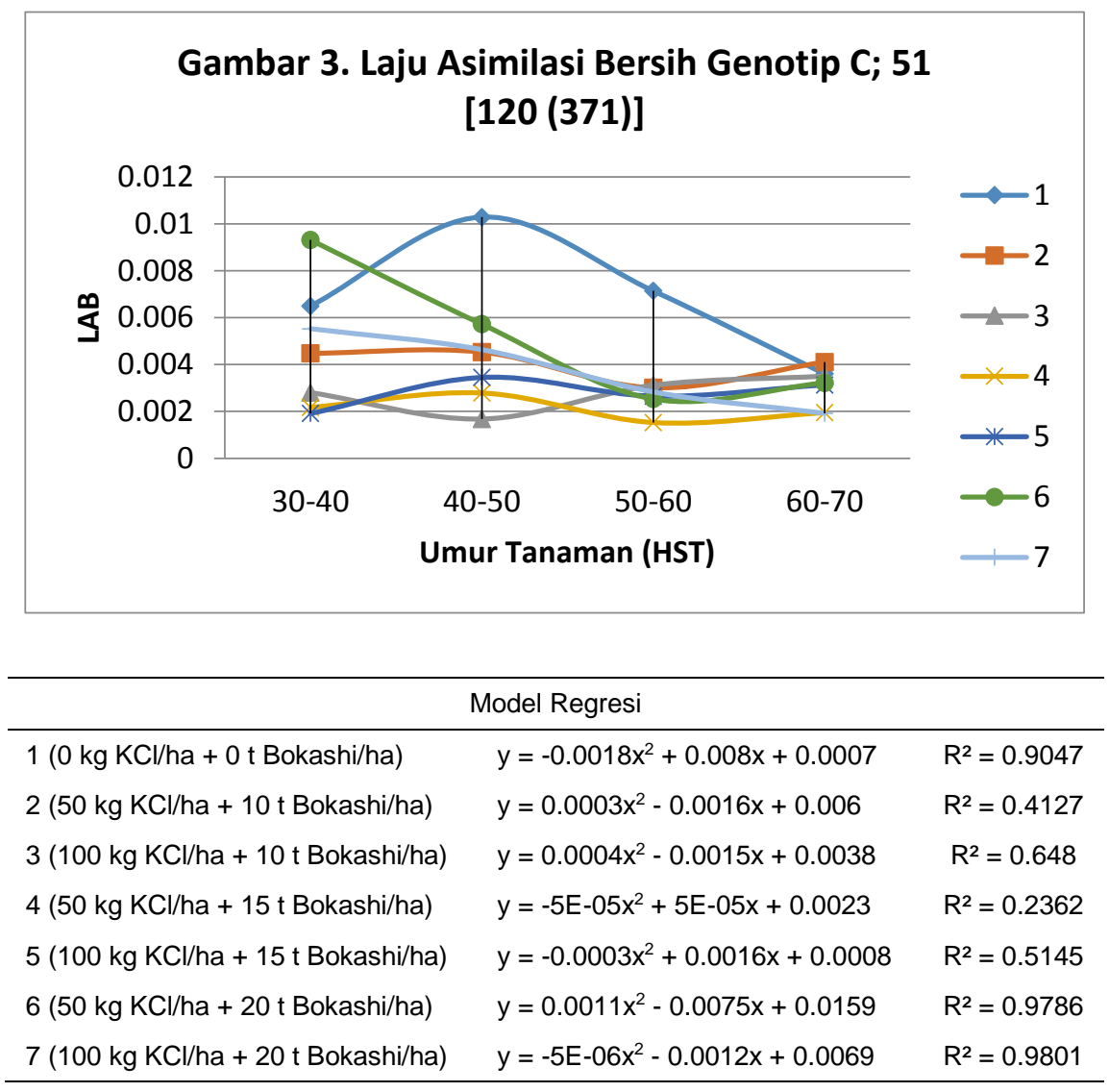




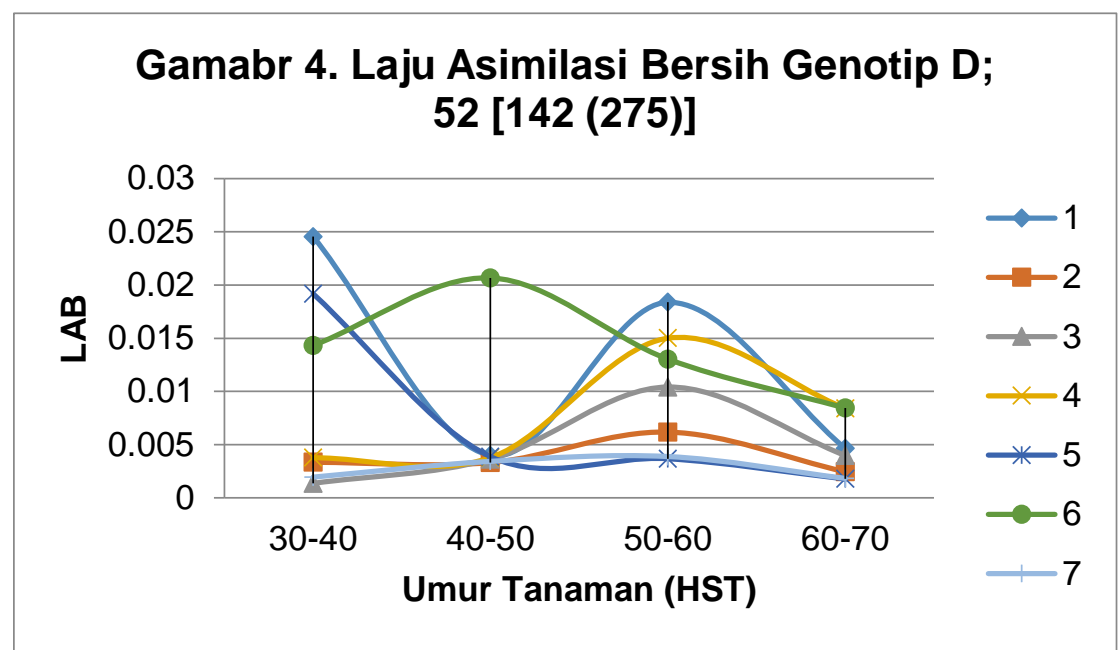

\begin{tabular}{|c|c|c|}
\hline \multicolumn{3}{|c|}{ Model Regresi } \\
\hline $1(0 \mathrm{~kg} \mathrm{KCl} / \mathrm{ha}+0$ t Bokashi/ha $)$ & $y=0.0017 x^{2}-0.0131 x+0.0328$ & $R^{2}=0.3655$ \\
\hline $2(50 \mathrm{~kg} \mathrm{KCl} / \mathrm{ha}+10$ t Bokashi/ha) & $y=-0.0009 x^{2}+0.0046 x-0.0009$ & $R^{2}=0.4326$ \\
\hline $3(100 \mathrm{~kg} \mathrm{KCl} / \mathrm{ha}+10$ t Bokashi/ha) & $y=-0.0022 x^{2}+0.0124 x-0.0097$ & $R^{2}=0.6548$ \\
\hline $4(50 \mathrm{~kg} \mathrm{KCl} / \mathrm{ha}+15$ t Bokashi/ha $)$ & $y=-0.0017 x^{2}+0.0108 x-0.0068$ & $R^{2}=0.5022$ \\
\hline $5(100 \mathrm{~kg} \mathrm{KCl} / \mathrm{ha}+15$ t Bokashi/ha) & $y=0.0034 x^{2}-0.022 x+0.037$ & $R^{2}=0.928$ \\
\hline $6(50 \mathrm{~kg} \mathrm{KCl} / \mathrm{ha}+20$ t Bokashi/ha $)$ & $y=-0.0027 x^{2}+0.0112 x+0.0067$ & $\mathrm{R}^{2}=0.811$ \\
\hline $7(100 \mathrm{~kg} \mathrm{KCl} / \mathrm{ha}+20$ t Bokashi/ha) & $y=-0.0009 x^{2}+0.0044 x-0.0017$ & $R^{2}=0.9664$ \\
\hline
\end{tabular}




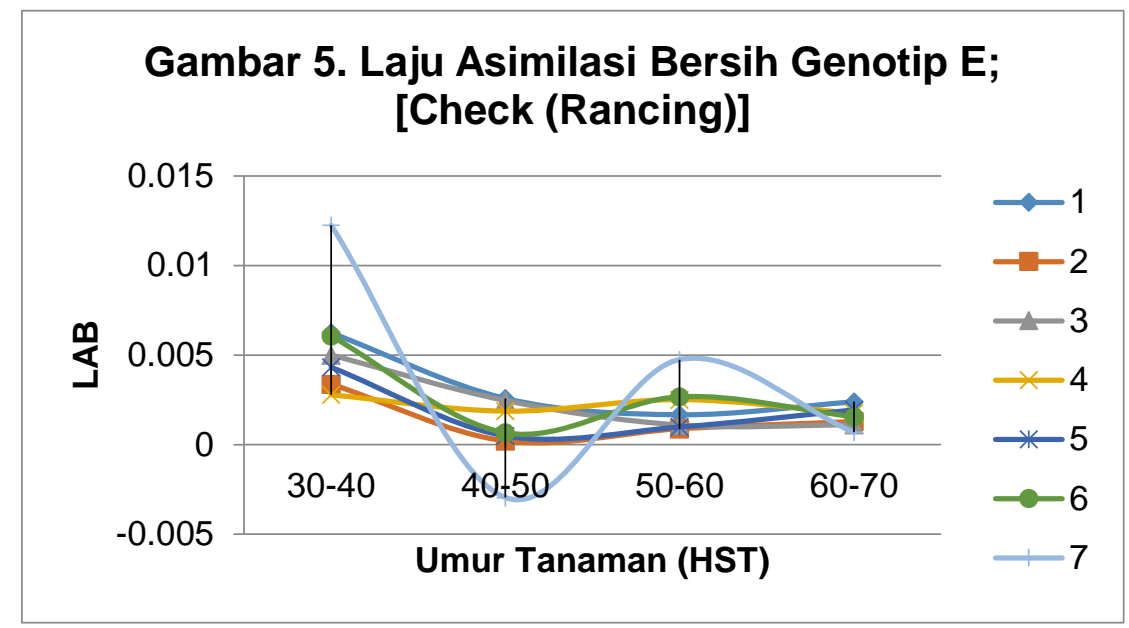

\begin{tabular}{|c|c|c|}
\hline \multicolumn{3}{|c|}{ Model Regresi } \\
\hline $1(0 \mathrm{~kg} \mathrm{KCl} / \mathrm{ha}+0$ t Bokashi/ha) & $y=0.0011 x^{2}-0.0067 x+0.0118$ & $R^{2}=0.995$ \\
\hline $2(50 \mathrm{~kg} \mathrm{KCl} / \mathrm{ha}+10$ t Bokashi/ha $)$ & $y=0.0009 x^{2}-0.005 x+0.0073$ & $R^{2}=0.8472$ \\
\hline $3(100 \mathrm{~kg} \mathrm{KCl} / \mathrm{ha}+10$ t Bokashi/ha) & $y=0.0006 x^{2}-0.0045 x+0.0089$ & $R^{2}=0.9998$ \\
\hline $4(50 \mathrm{~kg} \mathrm{KCl} / \mathrm{ha}+15$ t Bokashi/ha) & $y=4 E-05 x^{2}-0.0004 x+0.003$ & $R^{2}=0.4048$ \\
\hline $5(100 \mathrm{~kg} \mathrm{KCl} / \mathrm{ha}+15 \mathrm{t}$ Bokashi/ha $)$ & $y=0.0012 x^{2}-0.0066 x+0.0096$ & $R^{2}=0.9138$ \\
\hline $6(50 \mathrm{~kg} \mathrm{KCl} / \mathrm{ha}+20$ t Bokashi/ha) & $y=0.0011 x^{2}-0.0065 x+0.011$ & $R^{2}=0.6685$ \\
\hline $7(100 \mathrm{~kg} \mathrm{KCl} / \mathrm{ha}+20$ t Bokashi/ha) & $y=0.0028 x^{2}-0.0166 x+0.0244$ & $R^{2}=0.5288$ \\
\hline
\end{tabular}

\section{Laju Tumbuh Tanaman}

Laju pertumbuhan tanaman berubah secara kontinyu, dimana pertumbuhan dibatasi oleh perubahan abiotik dan pengaruh biotik (Poorter \& Garnier, 2007). Nilai determinasi $\left(R^{2}\right)$ yang mendekati 1 menyatakan bahwa model persamaan pada perlakuan tersebut ideal terhadap laju tumbuh tanaman. Pada Genotip A (Gambar 6), perlakuan 3 memiliki memiliki persamaan yang ideal dibandingkan dengan perlakuan lainnya dengan nilai determinasi 0,9999 atau $99,99 \%$. Pada Genotip B (Gambar 7), perlakuan 2 memiliki memiliki persamaan yang ideal dibandingkan dengan perlakuan lainnya dengan nilai determinasi 0,9197 atau $91,97 \%$. Pada Genotip C (Gambar 8), perlakuan 6 memiliki memiliki persamaan yang ideal dibandingkan dengan perlakuan lainnya dengan nilai determinasi 
0,9997 atau $99,97 \%$. Pada Genotip D (Gambar 9), perlakuan 2 memiliki memiliki persamaan yang ideal dibandingkan dengan perlakuan lainnya dengan nilai determinasi 0,9319 atau 93,19\%. Pada Genotip E (Gambar 10), perlakuan 3 memiliki memiliki persamaan yang ideal dibandingkan dengan perlakuan lainnya dengan nilai determinasi 0,9986 atau $99,86 \%$. Kurva pertumbuhan yang ideal berbentuk $S$ (sigmoid).

Kurva membentuk tiga fase utama dalam pertumbuhan tanaman yaitu : fase logaritmik, fase linier, dan fase penuaan (Salisbury dan Ross, 1995). Pada fase logaritmik, ukuran bertambah eksponensial secara dengan waktu (t). Ini berarti bahwa laju pertumbuhan (dv/dt) lambat pada awalnya, tapi kemudian terus meningkat. Pada fase linier, pertambahan ukuran berlangsung secara konstan.Fase penuaan dicirikan oleh laju pertumbuhan yang menurun saat tumbuhan sudah mencapai kematangan dan mulai menua. Kurva lima genotip tidak semuanya berbentuk sigmoid, ini diduga karena pengaruh faktor lingkungan seperti adanya organisme pengganggu tanaman yang menyebabkan terganggunya pertumbuhan tanaman ubi jalar. Genotip dengan nilai $\mathrm{R}^{2}$ hampir mendekati 1 memiliki bentuk kurva sigmoid yang ideal.

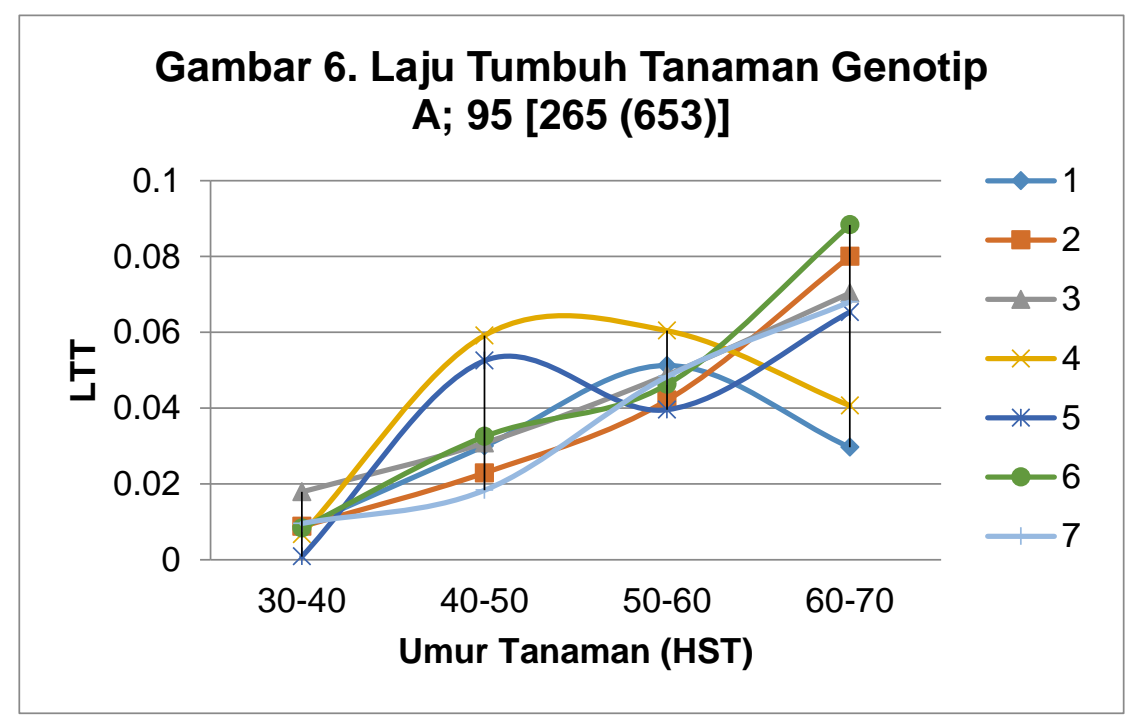




\begin{tabular}{|c|c|c|}
\hline \multicolumn{3}{|c|}{ Model Regresi } \\
\hline 1 (0 kg KCl/ha + 0 t Bokashi/ha) & $y=-0.0107 x^{2}+0.0619 x-0.0446$ & $R^{2}=0.8984$ \\
\hline $2(50 \mathrm{~kg} \mathrm{KCl} / \mathrm{ha}+10$ t Bokashi/ha) & $y=0.0059 x^{2}-0.0064 x+0.0099$ & $R^{2}=0.9967$ \\
\hline $3(100 \mathrm{~kg} \mathrm{KCl} / \mathrm{ha}+10$ t Bokashi/ha) & $y=0.0022 x^{2}+0.0067 x+0.009$ & $R^{2}=0.9999$ \\
\hline $4(50$ kg KCl/ha + 15 t Bokashi/ha) & $y=-0.0181 x^{2}+0.1006 x-0.0744$ & $\mathrm{R}^{2}=0.9757$ \\
\hline $5(100 \mathrm{~kg} \mathrm{KCl} / \mathrm{ha}+15 \mathrm{t}$ Bokashi/ha) & $y=-0.0065 x^{2}+0.0505 x-0.038$ & $\mathrm{R}^{2}=0.7714$ \\
\hline $6(50 \mathrm{~kg} \mathrm{KCl} / \mathrm{ha}+20$ t Bokashi/ha) & $y=0.0045 x^{2}+0.003 x+0.0028$ & $R^{2}=0.9778$ \\
\hline $7(100 \mathrm{~kg} \mathrm{KCl} / \mathrm{ha}+20$ t Bokashi/ha) & $y=0.0027 x^{2}+0.0069 x-0.0016$ & $\mathrm{R}^{2}=0.9772$ \\
\hline
\end{tabular}

Pemberian kombinasi pupuk $\mathrm{KCl}$ dan Bokashi diharapkan dapat meningkatkan pertumbuhan tanaman karena tanah menjadi kaya akan air dan unsur hara. Bokashi yang tercampur dengan bahan mineral tanah mempunyai pengaruh yang besar terhadap kapasitas pegang air, ini akan meningkatkan jumlah $\mathrm{K}$ yang tersedia bagi tanaman karena gerakan ion $\mathrm{K}$ melalui proses difusi bergantung pada kadar lengas tanah (Munawar, 2011). Menurut Gardner et al., (1991) laju pertumbuhan tanaman akan terus mengalami peningkatan mulai dari fase awal vegetatif sampai fase awal generatif, setelah memasuki fase generatif laju pertumbuhan akan terus mengalami penurunan. Unsur kalium yang terdapat pada kombinasi $\mathrm{KCl}$ dan bokashi jerami sangat berperan dalam pertumbuhan tanaman sehingga pengaruh kombinasi pupuk bervariasi terhadap laju pertumbuhan tanaman ubi jalar.

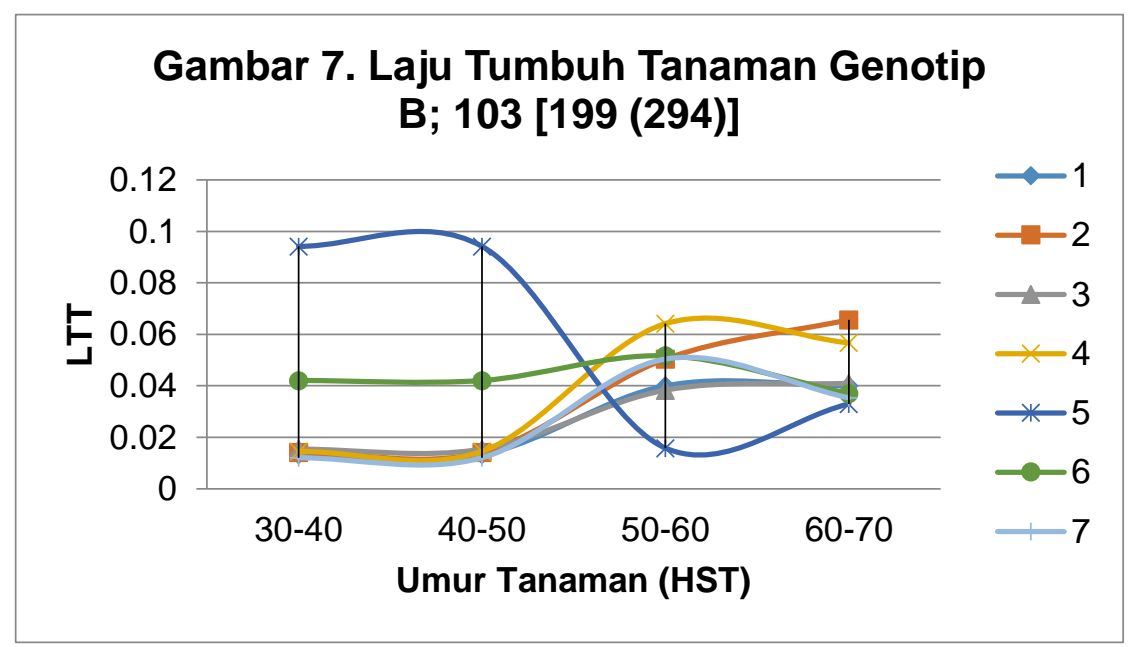




\begin{tabular}{|c|c|c|}
\hline \multicolumn{3}{|c|}{ Model Regresi } \\
\hline 1 (0 kg KCl/ha + 0 t Bokashi/ha) & $y=-3 E-17 x^{2}+0.0107 x-3 E-16$ & $\mathrm{R}^{2}=0.8$ \\
\hline $2(50 \mathrm{~kg} \mathrm{KCl} / \mathrm{ha}+10 \mathrm{t}$ Bokashi/ha $)$ & $y=0.0038 x^{2}+1 E-05 x+0.0075$ & $\mathrm{R}^{2}=0.9197$ \\
\hline $3(100 \mathrm{~kg} \mathrm{KCl} / \mathrm{ha}+10 \mathrm{t}$ Bokashi/ha) & $y=0.0007 x^{2}+0.0066 x+0.006$ & $\mathrm{R}^{2}=0.8425$ \\
\hline $4(50 \mathrm{~kg} \mathrm{KCl} / \mathrm{ha}+15 \mathrm{t}$ Bokashi/ha $)$ & $y=-0.0019 x^{2}+0.027 x-0.0158$ & $\mathrm{R}^{2}=0.7328$ \\
\hline $5(100 \mathrm{~kg} \mathrm{KCl} / \mathrm{ha}+15$ t Bokashi/ha $)$ & $y=0.0043 x^{2}-0.0476 x+0.1462$ & $R^{2}=0.6986$ \\
\hline $6(50 \mathrm{~kg} \mathrm{KCl} / \mathrm{ha}+20 \mathrm{t}$ Bokashi/ha $)$ & $y=-0.0037 x^{2}+0.0178 x+0.0263$ & $\mathrm{R}^{2}=0.4918$ \\
\hline $7(100 \mathrm{~kg} \mathrm{KCl} / \mathrm{ha}+20$ t Bokashi/ha $)$ & $y=-0.0038 x^{2}+0.0297 x-0.0184$ & $\mathrm{R}^{2}=0.6036$ \\
\hline
\end{tabular}

\section{Gambar 8. Laju Tumbuh Tanaman Genotip}

C; 51 [120 (371)]
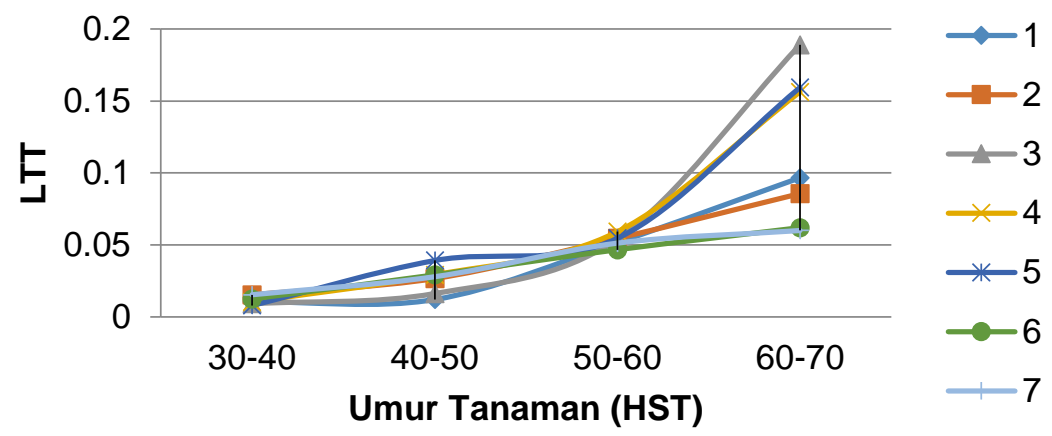

\begin{tabular}{|c|c|c|}
\hline \multicolumn{3}{|c|}{ Model Regresi } \\
\hline 1 (0 kg KCl/ha + 0 t Bokashi/ha) & $y=0.0108 x^{2}-0.0243 x+0.0223$ & $R^{2}=0.9894$ \\
\hline $2(50 \mathrm{~kg} \mathrm{KCl} / \mathrm{ha}+10 \mathrm{t}$ Bokashi/ha) & $y=0.005 x^{2}-0.0009 x+0.0107$ & $R^{2}=0.9969$ \\
\hline $3(100 \mathrm{~kg} \mathrm{KCl} / \mathrm{ha}+10$ t Bokashi/ha) & $y=0.0319 x^{2}-0.1019 x+0.0825$ & 0.9896 \\
\hline $4(50 \mathrm{~kg} \mathrm{KCl} / \mathrm{ha}+15 \mathrm{t}$ Bokashi/ha) & $y=0.0196 x^{2}-0.0512 x+0.0449$ & 0.9876 \\
\hline $5(100 \mathrm{~kg} \mathrm{KCl} / \mathrm{ha}+15 \mathrm{t}$ Bokashi/ha) & $y=0.0184 x^{2}-0.0449 x+0.0397$ & $\mathrm{R}^{2}=0.9572$ \\
\hline $6(50 \mathrm{~kg} \mathrm{KCl} / \mathrm{ha}+20 \mathrm{t}$ Bokashi/ha $)$ & $y=-0.0003 x^{2}+0.0183 x-0.0056$ & $R^{2}=0.9997$ \\
\hline $7(100 \mathrm{~kg} \mathrm{KCl} / \mathrm{ha}+20$ t Bokashi/ha) & $y=-0.0009 x^{2}+0.0204 x-0.0053$ & $R^{2}=0.9746$ \\
\hline
\end{tabular}




\section{Gambar 9. Laju Tumbuh Tanaman Genotip D; 52 [142 (275)]}
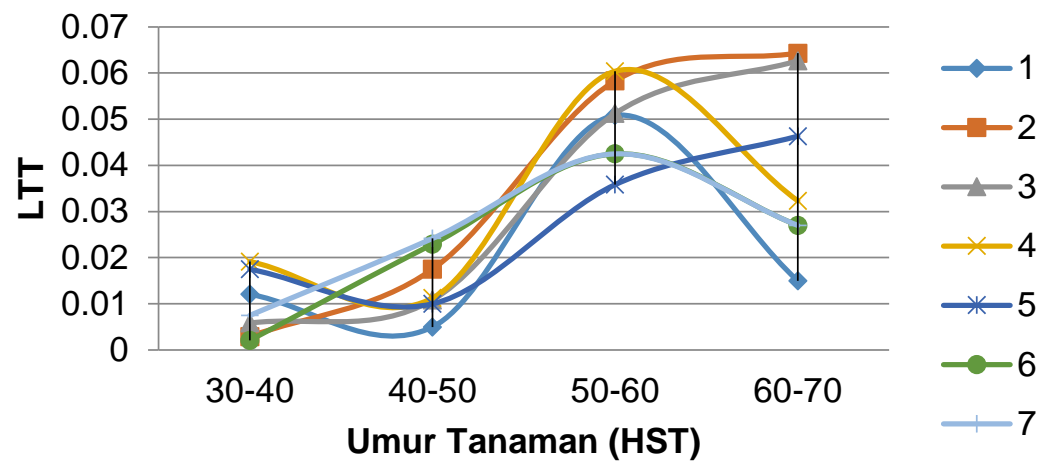

\begin{tabular}{|c|c|c|}
\hline \multicolumn{3}{|c|}{ Model Regresi } \\
\hline $1(0 \mathrm{~kg} \mathrm{KCl} / \mathrm{ha}+0$ t Bokashi/ha) & $y=-0.0072 x^{2}+0.0414 x-0.0289$ & $R^{2}=0.282$ \\
\hline $2(50 \mathrm{~kg} \mathrm{KCl} / \mathrm{ha}+10$ t Bokashi/ha $)$ & $y=-0.0021 x^{2}+0.0332 x-0.0312$ & $R^{2}=0.9319$ \\
\hline $3(100 \mathrm{~kg} \mathrm{KCl} / \mathrm{ha}+10$ t Bokashi/ha) & $y=0.0016 x^{2}+0.0131 x-0.0121$ & $R^{2}=0.915$ \\
\hline $4(50 \mathrm{~kg} \mathrm{KCl} / \mathrm{ha}+15$ t Bokashi/ha $)$ & $y=-0.005 x^{2}+0.0341 x-0.0166$ & $R^{2}=0.3542$ \\
\hline 5 (100 kg KCl/ha + 15 t Bokashi/ha) & $y=0.0045 x^{2}-0.0113 x+0.0218$ & $\mathrm{R}^{2}=0.8574$ \\
\hline $6(50 \mathrm{~kg} \mathrm{KCl} / \mathrm{ha}+20$ t Bokashi/ha) & $y=-0.0091 x^{2}+0.0548 x-0.0454$ & $R^{2}=0.9312$ \\
\hline $7(100 \mathrm{~kg} \mathrm{KCl} / \mathrm{ha}+20$ t Bokashi/ha) & $y=-0.008 x^{2}+0.0479 x-0.0341$ & $R^{2}=0.8978$ \\
\hline
\end{tabular}

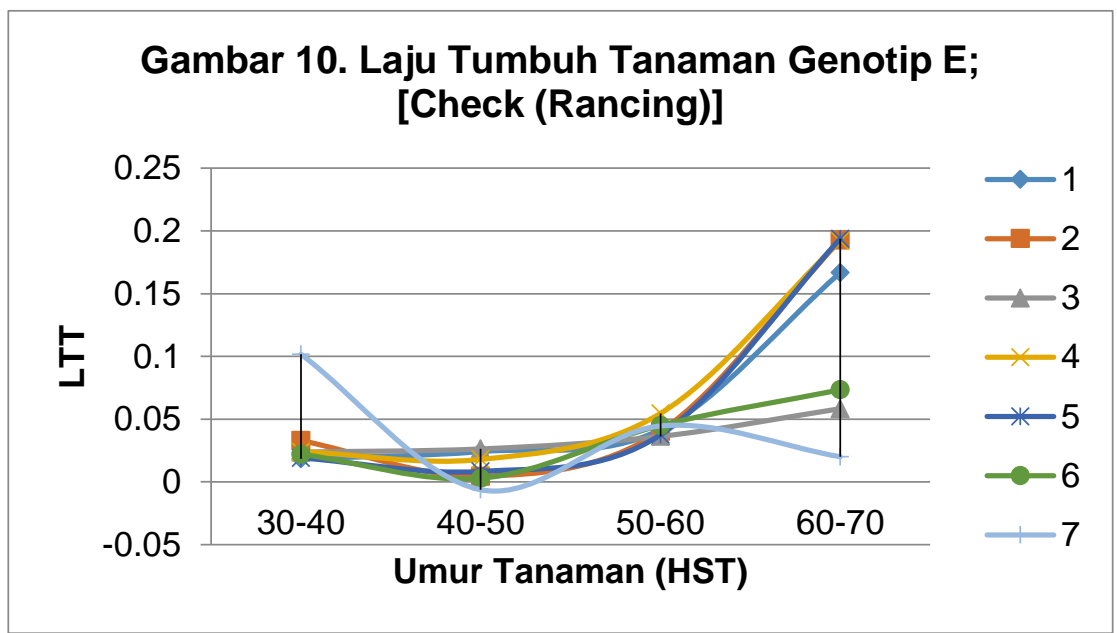




\begin{tabular}{|c|c|c|}
\hline \multicolumn{3}{|c|}{ Model Regresi } \\
\hline $1(0 \mathrm{~kg} \mathrm{KCl} / \mathrm{ha}+0 \mathrm{t}$ Bokashi/ha $)$ & $y=0.0298 x^{2}-0.1027 x+0.096$ & $R^{2}=0.9688$ \\
\hline $2(50 \mathrm{~kg} \mathrm{KCl} / \mathrm{ha}+10 \mathrm{t}$ Bokashi/ha) & $y=0.0451 x^{2}-0.1742 x+0.1646$ & $\mathrm{R}^{2}=0.9937$ \\
\hline $3(100 \mathrm{~kg} \mathrm{KCl} / \mathrm{ha}+10$ t Bokashi/ha) & $y=0.0049 x^{2}-0.0131 x+0.0322$ & $R^{2}=0.9986$ \\
\hline $4(50 \mathrm{~kg} \mathrm{KCl} / \mathrm{ha}+15 \mathrm{t}$ Bokashi/ha) & $y=0.0359 x^{2}-0.1256 x+0.1167$ & $\mathrm{R}^{2}=0.9916$ \\
\hline $5(100 \mathrm{~kg} \mathrm{KCl} / \mathrm{ha}+15 \mathrm{t}$ Bokashi/ha $)$ & $0.0418 x^{2}-0.1535 x+0.1352$ & $\mathrm{R}^{2}=0.9833$ \\
\hline $6(50 \mathrm{~kg} \mathrm{KCl} / \mathrm{ha}+20 \mathrm{t}$ Bokashi/ha $)$ & $y=0.0119 x^{2}-0.0398 x+0.0463$ & $R^{2}=0.8982$ \\
\hline $7(100 \mathrm{~kg} \mathrm{KCl} / \mathrm{ha}+20$ t Bokashi/ha) & $y=0.0208 x^{2}-0.1236 x+0.1927$ & $R^{2}=0.5691$ \\
\hline
\end{tabular}

\section{KESIMPULAN}

Pemberian

kombinasi pupuk kalium dan bokashi jerami menghasilkan kurva LAB dan LTT yang berbeda pada setiap genotip ubi jalar.Setiap genotip memberikan respons yang berbeda untuk setiap dosis kombinasi pupuk yang diberikan.

$$
\text { Ubi jalar yang di }
$$
tanam di lahan kering masih membutuhkan dosis $\mathrm{KCl}$ penuh, yaitu $100 \mathrm{~kg}$ $\mathrm{KCl} /$ ha.Dosis bokashi jerami yang dibutuhkan berkisar 10 - 20 t/ha.Hanya genotip B; 103 [199 (294)] yang respons terhadap subtitusi $\mathrm{KCl}$ dengan bokashi jerami $10 \mathrm{t} / \mathrm{ha}$.

UCAPAN TERIMA KASIH

Riset ini didanai oleh RISPRO LPDP 2015/2016 kepada Dr.Sc.Agr. Ir. Agung Karuniawan, M.Sc.Agr.

\section{DAFTAR PUSTAKA}

Degras, L. 2003. Sweet potato. The Tropical Agriculturalist. Macmillan Publishers Ltd, Malaysia.

Gardner, F.P., R. Brent, Pearce, and R. L. Mitchell. 1991.

Fisiologi Tanaman Budidaya.

Penerjemah Herawati Susilo. Universitas Indonesia. Jakarta.

Hussein, S.M., I. Jaswir, P. Jamal, and $R$. Othman. 2014. Carotenoid Stability and Quantity of Different Sweet Potato Flesh Colour over Postharvest Storage Time. Advances in Environmental

Biology, 8(3): 667671. Journal home page:

http://www.aensiweb. com/aeb.html.

IFA (International Fertilizer Industry Association). 1992. World fertilizer Use Manual. 
Publication of International Fertilizer Industry Association (pp. 138-142).

Lu Jian-wei., Chen Fang., Xu

You-sheng., Wan

Yuan-fan., and Liu

Dong-bi. 2001. Sweet

Potato Response to

Potassium. Better

Crops International,

Vol. 15, No. 1.

Martodenso dan Suryanto,

M.A. 2001.Terobosan

Teknologi

Pemupukan dan

EraPertanian

Organik. Penerbit

Kanisius, Yogyakarta

Munawar, A. 2011. Kesuburan

Tanah dan Nutrisi

Tanaman.IPB Press, Bogor.

Nafi'ah, H. H., T. Nurmala., dan

A. Karuniawan. 2016.

Perbedaan

Komponen Hasil dan

Hasil 4 Genotip Ubi

Jalar di Lahan Basah

dan Lahan Kering

dengan Pemberian

Kombinasi Pupuk

Kalium dan Bokashi Jerami.Pangan, Vol.

25. Hal.13-20.

Onwueme, I. C., and Sinha, T. O. 1991.Field crop production in Tropical Africa, principles and practice (pp.267-275). CTA (Technical Centre for Agriculture and Rural Cooperation) Ede, The Netherlands. www.ccsenet.org/jour nal/index.php/jas/artic le/download/25233/16
914. Diakses 12 Maret 2014.

Pangaribuan,

Darwin

Habinsaran., Pratiwi,

Octa Liestia., dan

Lismawanti.2011.

Pengurangan

Pemakaian Pupuk

Anorganik dengan

Penambahan Bokashi

Serasah Tanaman

pada Budidaya

Tanaman Tomat. J.

Agron. Indonesia, 39

(3): 173 - 179.

Paulus, J. M. 2011.

Pertumbuhan dan

Hasil Ubi Jalar pada

Pemupukan Kalium

dan Penaungan

Alami pada Sistem

Tumpangsari dengan

Jagung. J. Agrivior, 10 (3): 260-271.

Poorter, H., and E. Garnier. 2007. Ecological

Significance of

Inherent in Relative

Growth Rate and Its

Components. In

Fuctional Plant

Ecology. F. I.

Pugnaire and $F$.

Valladare (ed.). p 67-

100. New York. CRC

Press. 724p.

Salisbury, F.B. dan Ross, C.W. 1995. Fisiologi

Tumbuhan Jilid 3. Penerjemah : Diah R. Lukman dan

Sumaryono. ITB Press, Bandung.

Som, D. 2007. Handbook of horticulture (pp. 512416). New Delhi: India Council of 
Agricultural

Research.

Stoskopf, Neil C. 1981.

Understanding Crop

Production.Reston

Publishing Company, Inc. Virginia.

Trehan, S. P. 2007. Efficiency of potassium utilization from soil as influenced by different potato cultivars in the absence and presence of green manure (Sesbania aculeate).Advanced in Horticultural SciencesJournal, 21(3), 156-164.

Warta Penelitian dan Pengembangan

Pertanian. 2009. Jerami Dapat Mensubstitusi Pupuk $\mathrm{KCl}$ ?. Balai Penelitian Tanah. (On-line). pustaka.litbang.depta n.go.id/publikasi/wr31 1092.pdf. Diakses 13 Oktober 2014.

Wibowo, B. P. 2006. Analisis dan Respons Pertumbuhan Tanaman Padi PadaStress Salinitas Dengan Penambahan Amonium dan Kalium. Skripsi. Universitas Sebelas Maret, Surakarta. 